УДК 347.73

DOI https://doi.org/10.32840/1813-338X-2020.3.2.13

\title{
В. В. Ліпинський
}

кандидат юридичних наук, доцент, директор

Навчально-наукового інституту права та міжнародно-правових відносин Університету митної справи та фрінансів

\section{ДО ПИТАННЯ ПРО КОНСТИТУЦІЙНІСТЬ ПЕНІ У ПОДАТКОВОМУ ПРАВІ}

У статті констатується необхідність дотримання балансу інтересів між правами та законними інтересами платників податків та тягарем, який на них покладається заходами забезпечення дисципліни платників податків у виконанні їх фріскальних обов'язків та для підтримки платоспроможності держави. Автор звертає увагу на особливості інструментарію відповідальності за податкові правопорушення, зокрема у частині пені. Аналізується правова природа пені у податковому праві і наводяться аргументи на користь твердження про законодавчу невизначеність щодо належності досліджуваного інституту до компенсаційних чи санкційних механізмів. Установлено, що вимоги ст. 61 Конституції України мають застосовуватись до сутності правового положення, а не його законодавчої назви. Автором зроблено висновки про сумнівність з точки зору недопустимості подвійної відповідальності застосування пені на суму податкових зобов'язань поруч із итрафом, що визначається у відсотковому відношенні до суми податкового зобов'язання та про недопустимість застосування пені до суми несплачених итрафрних санкцій у зв'язку із невідповідністю положень про пеню в Податковому кодексі України вимогам Конституції України.

Ключові слова: податкова відповідальність, пеня, подвійна відповідальність, невідповідність Конституиії України, податкові правопорушення.

Постановка проблеми та завдання дослідження. Сталий розвиток економіки України потребує перш за все конкретних та зрозумілих правил поведінки для учасників внутрішніх ринків. Одним із основних таких аспектів $€$ податкові правила, які безпосередньо впливають на економічний результат діяльності суб'єктів господарювання та інших платників податків й, іноді, мають визначальний характер при прийнятті рішення щодо доцільності здійснення тієї чи іншої підприємницької діяльності.

Одним із інститутів податкового права, який значною мірою впливає на ділову активність, $€$ відповідальність за порушення податкового законодавства. Недостатня дієвість' цього інституту небезпечна тим, що це послаблює платоспроможність держави і публічні фрінанси в цілому. Водночас, надмірна суворість відповідальності створює надмірний тягар на приватних осіб і, як засіб зменшення такого тягаря, породжує корупційну динаміку.

У зв'язку з цим дотримання балансу у відносинах податкової відповідальності $€$ не тільки обов'язковим з правової точки зору, але і економічно доцільним.
Разом із тим, інститут пені в податковому праві має подвійну природу - фрінансової санкції та компенсаційного механізму за користування чужими коштами, однак застосовується разом із механізмами фінансової відповідальності, що $є$ сумнівним з точки зору ст. 61 Конституції України, положення якої забороняють притягнення особи до одного виду відповідальності декілька разів.

У зв'язку із цим метою дослідження є встановлення відповідності інституту пені в податковому праві України вимогам ст. 61 Конституції України.

Аналіз публікацій та виклад основних положень дослідження. Дослідженням зазначеного питання займалась низка вітчизняних науковців, серед яких належить виокремити П. М. Дуравкіна, Б. Н. Закаряна, Б. М. Ковтуна та В. Т. Білоус, які приділили увагу пені окремо від інших інститутів податкової відповідальності.

Регулювання пені в ПК України в цілому $€$ неоднозначним та теоретично невизначеним, не дивлячись на наявність поняття та розкриття його змісту законодавцем. Зокрема, поняття пеня вживається в наступному контексті:

1) як складова грошового зобов'язання платника податків, поруч із основною сумою зобов'я- 
зання, фінансовою санкцією та санкцією за порушення у сорері ЗЄД як окремий від окреслених вище вид зобов'язання (п. 14.1.39 ПК України);

2) пеня визначається як сума коштів у вигляді відсотків, нарахування на суми податкових зобов'язань та/або суми штрафних (фінансових) санкцій, не сплачених у встановлені законодавством строки (п. 14.1.162 ПК України);

3) пеня не зазначається в переліку штрафних (фінансових) санкцій поруч із фріксованою сумою та/або відсотками, що справляються з осіб, які вчинили податкове правопорушення (п. 14.1.265 ПК України);

4) пеня визначається окремо від штрафних санкцій і в контексті їх скасування, де законодавець визначив, що пеня та штрафні санкції, нараховані на суму грошового зобов'язання, скасовану за результатами адміністративного чи судового оскарження, також підлягають скасуванню (п. 57.4 ПК України);

5) пеня також визначена окремо під штрафних санкцій в аспекті списання безнадійного податкового боргу (п. 101.1 ПК України) [2].

3 огляду на вищевикладені положення, законодавець не розглядає пеню як складову частину фінансової відповідальності разом із фінансовими санкціями, а вважає її природу іншою.

У цьому зв'язку належить розглянути деякі праці вітчизняних вчених. Зокрема В. Т. Білоус та В. М. Ковтун, досліджуючи правову природу фінансових санкцій, що застосовуються за порушення податкового законодавства, зазначають, що відповідно до податкового законодавства фінансово-правові санкції мають каральний (штраф) та правовідновлювальний (пеня) характер [3, с. 73].

В свою чергу Б. Н. Закарян вказує, що наразі невирішеними залишаються деякі аспекти, пов'язані із природою та особливістю пені. Так, вчений зазначає, що проблема відмежування способів забезпечення виконання податкового обов'язку від заходів юридичної відповідальності має важливе теоретичне і практичне значення. Пеня має подвійну природу: вона одночасно виступає способом забезпечення виконання обов'язку зі сплати податків і зборів та мірою податкової відповідальності. Більш того, на сьогодні пеня розглядається законодавцем як різновид санкції за порушення податкового законодавства [4, с. 94].

П. М. Дуравкін, досліджуючи правову природу пені в податковому праві, дійшов висновку про те, що пеня в податковому праві $є$ санкцією за порушення строків сплати податків і зборів, яке спричинило затримання податкових надходжень до відповідних бюджетів. Належність пені до мір податково-правової відповідальності зумовлюється її додатковим характером по відношенню до сум податків і зборів, які не були вчасно сплачені. Створюючи додаткові майнові обтяження для платника податків, забезпечуючи додаткові надходження до відповідних бюджетів, пеня має податково-правову природу компенсаційної санкції [5, с. 9].

Водночас, подібний висновок суперечить положенням законодавства, наведеним вище, оскільки фрактично розглядає пеню як одну із фінансових санкцій за порушення податкового законодавця, що не властиво чинній редакції ПК України.

Визначаючи правову природу пені, вчений стверджує про таке:

1) позиція законодавця щодо вказівки на пеню, як спосіб забезпечення або санкцію сама по собі не може бути визначальною для її правової природи;

2) вчасна і в повному обсязі сплата податків і зборів виключає нарахування пені;

3) пеня виступає доповненням до суми несплачених вчасно податків і зборів;

4) пеня $є$ додатковим обтяженням для платника податків, порівняно із його початковим обов'язком зі сплати податків і зборів;

5) нарахування пені $€$ наслідком спливу строків виконання обов'язку зі сплати податків і зборів;

6) обов'язок зі сплати пені виходить за межі виконання обов'язку зі сплати податків і зборів;

7) пеня компенсує затримку надходження до бюджетів передбачених сум податків і зборів;

8) величина пені складається з: а) встановленого законодавством відсоткового розміру пені; б) періоду прострочення сплати податків і зборів; в) суми, на яку нараховується пеня;

9) наразі пеня в податковому законодавстві $€$ компенсаційно-штрафною санкцією, що зумовлено її нарахуванням як на суму несплачених вчасно податків і зборів, так і на суму штрафів [5, с. 8].

Вищенаведені ознаки вказують на те, що пеня $€$ формою юридичної відповідальності за податкове правопорушення, тобто одним із негативних фінансових наслідків податкового правопорушення для порушника.

Зазначений висновок має декілька наслідків:

1) застосування пені має бути включено до переліку фінансових санкцій; 
2) одночасне застосування пені і штрафу, а також фрінансових санкцій у вигляді відсоткового співвідношення до суми невиконаного зобов'язання має бути предметом окремого дослідження;

3) застосування пені до штрафнии санкцій має бути предметом окремого дослідження.

Щодо цих питань, 3 метою спрямування подальших наукових досліджень, вважаємо за належне звернути увагу на таке. Оскільки пеня $\epsilon$ відповідальністю за правопорушення, і з огляду на відсутність цивільно-правових відносин у податковій сфрері, ії застосування можливе виключно як однієї із фрінансових санкцій. Виокремлення законодавцем глави 12 ПК України із загальних положень про фрінансові санкції $€$ необґрунтованим і пеня має становити окрему статтю в зазначеному розділі.

Зазначений висновок підтверджується і положеннями п.129.9.1-129.9.7 ПК України, який передбачає випадки анулювання/ненарахування пені, і встановлює правила, аналогічні правилам звільнення від відповідальності за податкові правопорушення.

Щодо одночасного застосування пені і штрафуу питання $є$ надзвичайно комплексним з огляду на положення ст. 61 Конституції України, відповідно до якої ніхто не може бути двічі притягнений до юридичної відповідальності одного виду за одне й те саме правопорушення [1].

Зазначене питання неодноразово досліджувалось в судовій практиці в цивільних та господарських справах (яким, власне і властивий інститут пені). Верховний Суд України, а потім і Касаційний Верховний Суд, дотримувались одночасно кількох позицій, неодноразово змінюючи їх.

Так, Касаційний господарський суд в Постановах від 19.09.2019 у справі № 904/5770/18, від 27.09.2019 у справі № 923/760/16, від 02.04.2019 у справі № 917/194/18, від 25.05.2018 у справі № 922/1720/17, від 09.02.2018 у справі № 911/2813/17, від 22.03.2018 у справі № 911/1351/17 дотримується позиції про те, що одночасне стягнення з учасника господарських відносин, який порушив господарське зобов'язання за договором, штрафу та пені не суперечить статті 61 Конституції України, оскільки згідно зі статтею 549 ЦК України пеня та штраф $є$ формами неустойки, а відповідно до статті 230 ГК України - видами штрафнних санкцій, тобто не $є$ окремими та самостійними видами юридичної відповідальності. У межах одного виду відповідальності може застосовуватися різний набір санкцій [6-11].
Водночас, така позиція не витримує критики з огляду на текст норми ст. 61 Конституції, яка, визначає, що ніхто не може бути двічі притягнений до юридичної відповідальності одного виду за одне й те саме правопорушення, фрактично забороняючи застосування одночасно двох санкцій за одне й те ж саме правопорушення.

Слідування логіці Касаційного господарського суду Верховного суду означало б, наприклад, припустимість з точки зору Конституції застосування кількох покарань одночасно за одне й те ж саме правопорушення (наприклад, застосування одночасно штрафру і позбавлення права займатись певною діяльністю).

При цьому, Верховний Суд України у Постанові у справі № 6-116цс13 від 6 листопада 2013 року зазначив, що встановлення різних видів цивільно-правової відповідальності за різні порушення умов договору, навіть із їх одночасним застосуванням, не свідчить про порушення положень ст. 61 Конституції України [12].

Іншими словами, зазначена правова позиція означає, що штрафр та пеня не можуть бути одночасно застосовані за одне й те ж саме правопорушення з огляду на положення Конституції. Одночасне застосування пені і штрафру $€$ допустимим у випадку їх застосування за різні правопорушення в межах одних і тих самих правовідносин.

Також вірною вдається позиція Верховного Суду України, висловлена в Постанові від 1 липня 2014 року у справі №11/5026/1925/2012, відповідно до якої суд касаційної інстанції, застосувавши до спірних правовідносин положення частини третьої статті 692, частини другої статті 536, частини другої статті 625 ЦК України, дійшов обґрунтованого висновку про те, що проценти за користування чужими грошовими коштами, які за умовами договору нараховуються за кожен день прострочення виконання зобов'язання, за своєю правовою природою, ураховуючи спосіб їх обчислення за кожен день прострочення, підпадають під визначення пені (частина третя статті 549 ЦК України), яка вже нарахована відповідно до пункту 7.2 договору в розмірі двох облікових ставок Національного банку України від несплаченої покупцем суми за кожен день прострочення за цей самий період, що не узгоджується з приписами статті 61 Конституції України, за змістом якої ніхто не може бути двічі притягнений до юридичної відповідальності одного виду за одне й те саме правопорушення [13].

Таким чином, Верховний Суд України дійшов висновку про те, що визначальним у вирішенні 
питання про подвійну відповідальність $є$ саме зміст механізму, що застосовується, у зв'язку із чим застосування неустойки двічі (у формі пені та штрафу, або пені та відсотків річних сформульованих як пеня) $€$ порушенням принципу недопустимості подвійної відповідальності.

На нашу думку єдиним шляхом розв'язання зазначеної проблеми є розмежування компенсаційного і санкційного характеру відповідальності.

Так, у випадку застосування штрафру у фріксованому розмірі (в якості санкції за правопорушення) застосування пені вдається можливим із тим, щоб компенсувати стороні, яка зазнала порушення своїх прав, втрати, яких вона зазнала.

Разом із тим, застосування пені із одночасним застосуванням штрафу у відсотковому співвідношенні до розміру зобов'язання, наприклад, відповідно до п.120-1.1 ст. 120-1 ПК України, із зростанням суми штрафу відповідно до строку порушення, має розглядатись як подвійна відповідальність, оскільки в такому разі порушник змушений двічі компенсувати втрати стороні, яка їх зазнала.

Стосовно нарахування пені на суму несплачених штрафних санкцій, вважаємо за необхідне окреслити наступну позицію. Оскільки пеня $€$ формою відповідальності, то вона може наставати за вчинене правопорушення i, з огляду на положення Конституції України, не більше одного разу. Застосування пені стосовно штрафних санкцій або затримки сплати узгоджених зобов'язань відрізняється своєю природою від застосування пені в інших випадках.

Цивільне право регулює зазначені відносини шляхом застосування пені та, окремим інститутом, відшкодування інфляційних витрат та витрат у вигляді відсотків річних за користування коштами. Більш того, саме такий зміст фактично передбачає п.129.4 ПК України, визначаючи пеню у розмірі 100-120 відсотків від розміру облікової ставки Національного банку України [2], хоча і застосовує поняття пені замість інфляційних витрат та відсотків за користування коштами.

У зв'язку із зазначеним, зазначені положення можуть застосовуватись виключно у разі зміни законодавства і встановлення їх компенсаційної природи, пов'язаної не з податковим правопорушенням як таким, а із затримкою щодо виконання зобов'язання і, відповідно, інфляційними втратами та відсотками за користування державними коштами. В такому випадку зазначений компенсаторний механізм не матиме властивостей пені і може застосовуватись одночасно із нею.

Висновки 3 дослідження. 3 огляду на вищенаведене, до врегулювання законодавцем питання застосування пені як компенсаторного механізму за затримку виконання зобов'язання у випадку несплати штрафних санкцій, а також врегулювання правового режиму пені шляхом її включення до переліку фінансових санкцій на підставі ПК України, положення ПК України про пеню не підлягають застосуванню з огляду на невідповідність вимогам Конституції України.

\section{Список використаної літератури:}

1. Конституція України : Закон України від 28 червня 1996 року № 254к/96-ВР. Дата оновлення: 1 січня 2020 року. URL: https://zakon. rada.gov.ua/laws/card/254к/96-вр.

2. Податковий кодекс України : Закон України від 2 грудня 2010 року № 2755-VI. Дата оновлення: 14 жовтня 2020 року. URL: https://zakon.rada. gov.ua/laws/show/2755-17\#Text.

3. Біолус В.Т., Ковтун В.М. Правова природа фрінансових санкцій, що застосовуються за порушення податкового законодавства. Наука $i$ правоохорона. 2013. № 4. C. 70-76. URL: http:// naukaipravoohorona.com/journal/ukr/2013_4/12.pdf.

4. Закарян Б.Н. Пеня в системі забезпечувальних засобів при регулювання відносин оподаткування. Журнал східноєвропейського права. 2014. № 2. С. 92-95. Режим доступу: http://nbuv.gov.ua/UJRN/jousepr_2014_2_14. URL: $\quad$ http://www.irbis-nbuv.gov.ua/cgi-bin/ irbis_nbuv/cgiirbis_64.exe?C21COM=2\&I21D $B N=\bar{U} J R N \& P 21 D B N=U J R N \& I M A G E \_F I L E$ DOWNLOAD $=1 \& \mathrm{Image}$ file_name=PDF/ jousepr_2014_2_14.pdf.

5. Дуравкін П.М. Пеня в податковому праві: між способом забезпечення і санкцією. Теорія $i$ практика правознавства : електрон. вид. 2015. T. 2, № 8. Режим доступу : http://tlaw.nlu. edu.ua/article/view/63820/59303.

6. Постанова Верховного Суду від 19 вересня 2019 року у справі № 904/5770/18. URL: https:// reyestr.court.gov.ua/Review/84420888.

7. Постанова Верховного Суду від 27 вересня 2019 року у справі № 923/760/16. URL: https:// reyestr.court.gov.ua/Review/84626225.

8. Постанова Верховного Суду від 2 квітня 2019 року у справі № 917/194/18. URL: https:// reyestr.court.gov.ua/Review/80923003.

9. Постанова Верховного Суду від 25 травня 2018 року у справі № 922/1720/17. URL: https:// reyestr.court.gov.ua/Review/74378024.

10.Постанова Верховного Суду від 9 лютого 2018 року у справі № 911/2813/17. URL: https:// reyestr.court.gov.ua/Review/72149821. 
11.Постанова Верховного Суду від 22 березня 2018 року у справі № 911/1351/17. URL: https:// reyestr.court.gov.ua/Review/73081562.

12.Постанова Верховного Суду України від 6 листопада 2013 року у справі № 6-116цс13.
URL: https://oda.court.gov.ua/sud1590/pravovipoziciivsu/6-116cs13.

13.Постанова Верховного Суду України від 1 липня 2014 року у справі № 3-31гс14. URL: https://reyestr.court.gov.ua/Review/39783863.

\section{Lipynskyi V. V. To the question of the constitutionality of the penalty in tax law}

In the article the author states the necessity of the proper balance maintenance between tax discipline and unnecessary fiscal responsibility scale to provide stability in states finances. Analysis of fiscal responsibility institute is carried out, with the particular accent on periodic penalty payment. Author analyses the legal nature of the periodic penalty payment within tax law and has stated uncertainty related to the place of periodic penalty payment within either punitive or compensatory mechanisms. It is established, that provisions of the Article 61 of the Constitution of Ukraine are applicable based on the legal nature of periodic penalty payment, not in view of its definition given by the statutes. Author infers that doubts arise with respect to constitutional acceptance of applying periodic penalty payment together with the fine, determined in percentage of the tax obligation, and about clear constitutional prohibition of applying periodic penalty payment to the unpaid amount of fine or other sanctions. Therefore, the periodic penalty payment within tax code of Ukraine should not be applied in practice based on the rule of law demands until legislation is amended.

Key words: tax liability, periodic penalty payment, ne bis in idem, being contradictory to constitutional provisions, tax offences. 